\title{
Aplicación de la microscopía óptica de fluorescencia al estudio textural del clínker de cemento portland
}

\author{
Application of the fluorescence \\ ligth microscopy in the textural study \\ of portland cement clinker
}

ANGEL RODRIGUEZ REY, MODESTO MONTOTO SAN MIGUEL, LOPE CALLEJA ESCUDERO, VICENTE GOMEZ RUIZ DE ARGANDOÑA, LUIS MIGUEL SUAREZ DEL RIO Area de Petrología y Geoquímica. Departamento de Geología. Universidad de Oviedo 33080 - Oviedo/España

\section{RESUMEN}

Se presenta la utilidad de la microscopia óptica de fluorescencia para el estudio textural del clínker de cemento Portland, especialmente su porosidad. Se comentan los fundamentos y modalidades de la técnica, y se describe el método recomendado de preparación de muestras. La utilización de la microscopia de fluorescencia permite un estudio más fácil de ia porosidad, obteniéndose imágenes muy apropiadas para su cuantificación mediante técnicas automatizadas. Además, las muestras para fluorescencia pueden ser estudiadas complementariamente por microscopia óptica de polarización por luz reflejada.

\section{SUMMARY}

The application of fluorescence light microscopy in the textural study of Portland cement clinker, specially its porosity, is presented. Principles and types of the technique are comented and the suggested sample preparation method is described. The use of fluorescence microscopy allows an easier study of the clinker porosity, and very proper images for automated quantification can be obtained. Besides, the samples can also be observed by reflected-light polarizing microscopy.

\section{INTRODUCTION}

The most currently microscopic technique used in the study of Portland cement clinker is the polarizing microscopy. However, for the study of specific aspects, other more proper techniques can be applied. In particular, the fluorescence ligth microscopy is specially convenient for the observation of the clinker porosity. The importance of this textural characteristic has been remarked by many author (for instance, [1] and [2], as very useful information about the manufacturing process of Portland cement clinker, as well as about some of its properties (specially its grindability) can be obtained.

The fluorescence light microscopy has sometimes been used by some authors in the textural study of concrete [3], and of the Portland cement clinker [4]. 


\section{DESCRIPCION DE LA TECNICA}

Como ya es conocido, la fluorescencia es la radiación que emite una sustancia como consecuencia de haber sido excitada por otra radiación que incide sobre ella. La microscopia óptica de fluorescencia se aplica al estudio de las sustancias que, al ser excitadas, emiten una radiación ópticamente visible. Sin embargo, también pueden estudiarse otras, siempre que se impregnen con sustancias fluorescentes denominadas genéricamente fluorocromos.

Ninguna de las fases mineralógicas del clínker emite fluorescencia ópticamente visible. Por lo tanto, la microscopía de fluorescencia no suministra información sobre las características mineralógicas del clínker. En cambio, facilita la observación textural destacando características como la porosidad (macro y micro) que, a veces, presenta ciertos problemas para su estudio mediante microscopía de polarización. Para ello los poros de la muestra deben rellenarse con una resina "teñida" con un colorante fluorescente como, por ejemplo, la rodamina B.

La microscopía de fluorescencia puede clasificarse según varios criterios (naturaleza de la radiación de excitación utilizada, modo de iluminación de la muestra, etc.).

La radiación de excitación está en función de la sustancia fluorescente. En el caso de la rodamina, ha de ser radiación de unos $550 \mathrm{~nm}$ de longitud de onda (luz verde); no es necesario, entonces, utilizar fuentes de iluminación especiales ya que las lámparas de halógeno suministran la suficiente intensidad de esta radiación verde para excitar la fluorescencia de la rodamina.

Según el modo en que la radiación de excitación llega a la muestra se distinguen:

- Microscopía de fluorescencia por luz transmitida.

- Microscopía de fluorescencia por luz reflejada.

Es más apropiada la segunda modalidad, ya que la preparación de muestras es más sencilla, y la información que puede obtenerse es, en ambos casos, la misma. Además, con los modernos componentes de los equipos (reflectores, filtros, etc.), la microscopía por reflexión supera a la de transmisión al simplificarse mucho el equipo instrumental necesario, siendo, además, mayor la intensidad de la fluorescencia que se observa.

\section{DESCRIPTION OF THE TECHNIQUE}

As it is known, fluorescence is the radiation that a substance emits as result of the excitation by an incident radiation. The fluorescence light microscopy can be applied to the study of substances that emit, when excited, visible fluorescence radiation. Nevertheless other materials can be studied if they are impregnated with fluorescent substances called fluorochromes.

None of the clinker phases emits visible fluorescence. So, no mineralogical information can be obtained by means of this technique. On the other hand, the fluorescence microscopy makes easier the textural study of some characteristics like porosity (macro and micro) which, sometimes, are difficult to be observed under polarizing microscopy. The pores of the sample must be filled with a resin stained with a fluorescent colorant as Rhodamine $B$, for instance.

The fluorescence light microscopy can be classified according to several factors (nature of excitation radiation, way of illumination of the sample...).

The excitation radiation depends on the fluorescent material. It must be a radiation of $550 \mathrm{~nm}$ wavelength (green light) in the case of Rhodamine; so it is not necessary to use special illumination sources, since halogen lamps provide enough green intensity to excite fluorescence in the Rhodamine.

According to the way in which the excitation radiation reaches the sample, two modes can be distinguished:

\section{- Transmitted light fluorescence microscopy.}

\section{- Reflected light fluorescence microscopy.}

The latter is more convenient. The information obtained by both modes is the same, and the sample preparation is easier in the second case. Moreover, modern components of equipments (reflectors, filters, etc.) make the fluorescence observed under reflected light stronger than that observed by transmitted light, and make more simple the required equipment. 
De hecho, es posible adaptar muchos microscopios de reflexión para fluorescencia sin más que sustituir el reflector para luz polarizada por otro especial de fluorescencia, que ya lleva incorporados los distintos tipos de filtros necesarios (de excitación y de supresión).

Pueden encontrarse más detalles sobre microscopía de fluorescencia, modalidades, equipos, aplicaciones, etc., en muchos manuales de microscopía, como por ejemplo [5].

\section{APLICACION AL ESTUDIO DEL CLINKER}

Mediante esta técnica, el estudio de una muestra convenientemente preparada permite, como ya se ha mencionado, una más fácil y exacta caracterización de su porosidad.

Además, estas muestras sirven igualmente para estudios por microscopía óptica de polarización por reflexión y pueden ser atacadas con los reactivos normalmente utilizados (Nital, agua destilada, etc.). Así pueden obtenerse al menos dos imágenes con distinta, pero complementaria, información de una misma zona de la muestra.

La figura 1 es una imagen de una sección pulida de clínker, previamente impregnado con resina fluorescente, obtenida por microscopía de fluorescencia por reflexión. La figura 2 es la imagen de la misma zona, pero observada

Figura 1.-Sección pulida de clínker, previamente impregnado con resina fluorescente, observada mediante microscopia de fluorescencia por luz reflejada. Sólo la porosidad es visible y por lo tanto su estudio puede realizarse más fácilmente, en especial si se utilizan técnicas automatizadas.

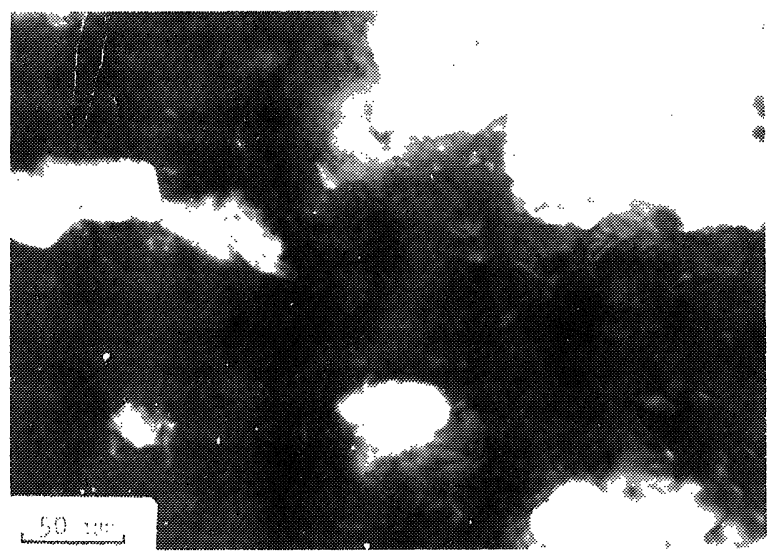

Figure 1.-Polished section of clinker, previously filled with fluorescent resin, observed by refiected-light fluorescence microscopy. Only porosity is visible; its study can be performed in an easier way, specially under automated techniques.
In fact, many reflected-light microscopes can be adapted to work in fluorescence, by simply substituting the reflector used in polarizing microscopy for another special one which incorporates all the different types of required filters (excitation and barrier filters).

More details about fluorescence microscopy, like types, equipment, applications, etc., can be found in many textbooks on microscopy, as [5] for instance.

\section{APPLICATION TO THE STUDY OF PORTLAND CEMENT CLINKER}

The fluorescence light microscopy applied to a convenient sample permits, as stated before a more accuracy and easier characterization of porosity.

Besides, these sample can be equally studied by reflected light polarizing microscopy, and also can be normally etched. In this way, at least two images with different, but complementary information, can be obtained from the same area of the sample.

So, figure 1 presents an image of a polished section of clinker filled previously with fluorescent resin, observed under reflectedlight fluorescence microscopy. Figure 2 is a view of the same area but under polarizing

Figura 2.-La misma zona observada mediante microscopía de polarización por luz reflejada. La porosidad no se discrimina tan fácilmente y podría confundirse con los granos atacados de cal libre.

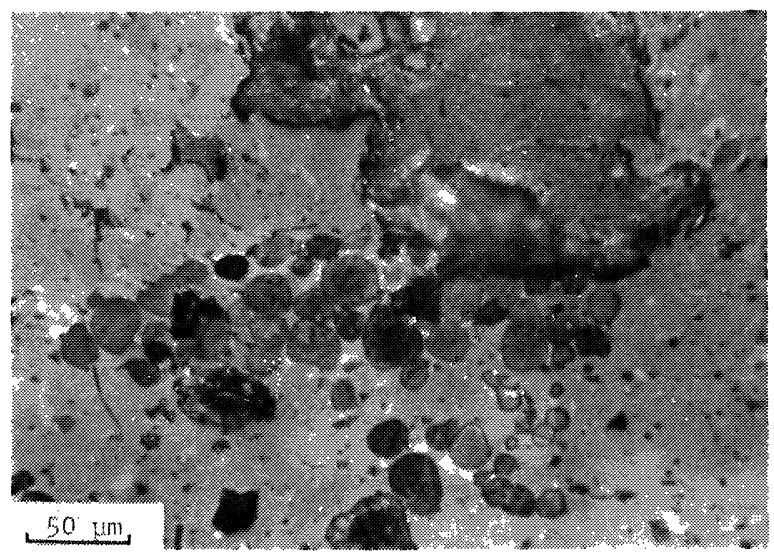

Figure 2.- The same area but under reflected-light polarizing microscopy. The porosity can not be so easily discriminated as it can be confused with the etched tree lime grains. 
mediante microscopía de polarización. La muestra había sido atacada con agua destilada, apareciendo algunos granos de cal libre primaria, muy similares, en cuanto a reflectividad, a la resina. Son evidentes las ventajas de la imagen obtenida por fluorescencia para el estudio de la porosidad.

La imagen por fluorescencia es prácticamente "binaria", es decir, presenta sólo dos valores de luz (negro y rojo). Por ello es muy apropiada para su estudio y cuantificación por técnicas automatizadas como el proceso digital de imágenes.

\section{PREPARACION DE MUESTRAS}

El método de preparación de muestras es similar al utilizado en materiales rocosos por [6], [7] y [8], que garantiza una impregnación completa de los espacios vacíos, que es el principal problema para la obtención de muestras idóneas.

Para conseguir los mejores resultados, conviene obtener una sección diametral del gránulo, antes de su impregnación. En el caso de clínkeres muy frágiles hay que llevar a cabo una impregnación previa del gránulo entero, utilizando también resina fluorescente.

Hay que evitar la aparición de "artefactos" (características morfológicas no originales de la muestra, sino introducidas durante el proceso de fabricación), especialmente los espacios vacíos debidos a saltaciones de granos, etc., que darían lugar a interpretaciones erróneas de las características de la porosidad. Para ello pueden utilizarse sierras de baja deformación, de pocas revoluciones y provistas de discos de muy poco espesor $(0.3 \mathrm{~mm})$ de borde continuo diamantado. El daño introducido durante esta etapa de corte puede eliminarse por desbaste con CSi de grano F600 seguido del de grano F1000.

Las resinas epoxídicas dan buenos resultados como medio de impregnación. Es recomendable que sean bastante fluidas. En todo caso pueden fluidificarse por adición de estireno. Para hacerlas fluorescentes se les añade un $0.2 \%$ en peso de rodamina $B$ que se disuelve previamente en estireno (un $40 \%$ en volumen de la resina).

La impregnación propiamente dicha se realiza en dos etapas:

a) por vacío.

b) bajo presión. microscopy. The sample had been etched with distilled water and shows some grains of free lime, very similar in reflectiveness to the resin. The image obtained under fluorescence microscopy presents obvious advantages for the study of porosity.

This image is binary in practice, that is, it has only two "values of light" (black and red). So, it is very appropriate for its study and quantification by means of automated techniques as digital image processing.

\section{SAMPLE PREPARATION}

The sample preparation method is similar to that used with rocks [6], [7] and [8]. This method guarantees the total filling of voids, which is the main problem to overcome in the preparation of proper samples.

In order to achieve the best results, it is convenient to obtain a diametral section of the granule before impregnation. In case of very brittle clinkers a first impregnation of the whole granule must be performed, also using fluorescent resin.

The development of "artefacts" (non-original characteristics of the sample, but introduced during its preparation) must be avoided, specially those voids due to grain loses, etc., which would lead to erroneous interpretations of porosity. With this purpose, rock saws of very low deformation, with very thin $(0.3 \mathrm{~mm})$ diamond-bonded continuous ring blades rotating at very low speed, can be used. The damage developed during this sawing stage can be removed by grinding with SiC F600 followed by the finer F1000.

The epoxy resins provide goog results as impregnating media. They must be quite fluid. Anyway, they can be made more fluid adding Styrol. To make them fluorescent Rhodamine $B$ must be added in a $0.2 \%$ amount, previously dissolved in Styrol (in an amount equal to $40 \%$ in volume of the resin).

The actual filling is performed in two steps:

- under vacuum.

- under pressure. 
Ambas operaciones se llevan a cabo en un recipiente metálico especial, (figura 3 ) donde se puede hacer el vacio y en el que las muestras pueden ser sometidas a presión hidróstatica.
Both of them are performed in a special metalic vessel (figure 3) in which the vacuum can be obtained and which can be yielded, besides, under pressure on a hydraulic press.

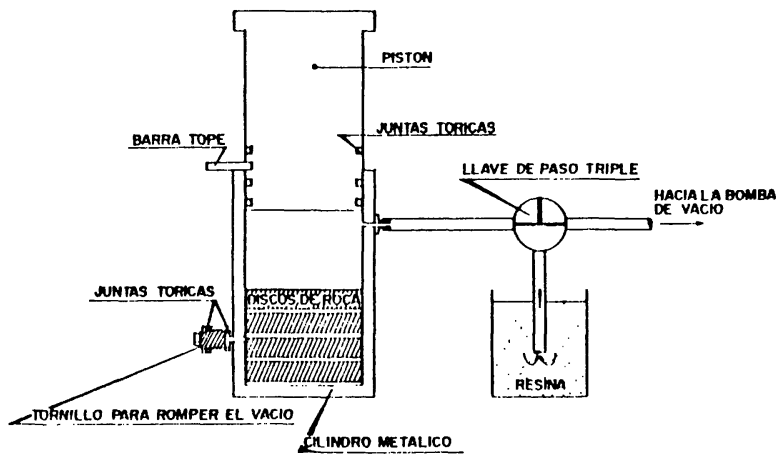

Figura 3.-Esquema del recipiente donde se lleva a cabo la impregación de las muestras.
Figure 3.-Schematic view of the vessel where the sample impregnation is performed.
En la primera etapa, se somete al gránulo de clínker, seccionado y pulido, a un vacio de $10^{-1}$ torr, como mínimo, y en estas condiciones se introduce la resina en el sistema.

En la segunda etapa, y para asegurar la impregnación completa, se somete la muestra parcialmente impregnada y sumergida en el seno de la resina, a una presión hidrostática de $100 \mathrm{kp} / \mathrm{cm}^{2}$ durante $15 \mathrm{~min}$. De esta forma se fuerza a la resina para que penetre en todos los intersticios de los poros.

Una vez concluido el proceso de impregnación se dejan secar las muestras fuera del recipiente, cubiertas únicamente por una fina capa de resina. Cuando haya solidificado se elimina la capa de recubrimiento con CSi F600. La preparación de la muestra finaliza con las etapas normales de pulimento grueso y final.

\section{CONCLUSIONES}

La microscopía óptica de fluorescencia es una técnica apropiada para el estudio textural del clínker de cemento Portland al permitir una observación óptima de la porosidad.

El proceso de preparación de muestras favorece la consolidación de clínkeres muy frágiles.

Las muestras preparadas para esta técnica pueden, además, ser estudiadas mediante microscopía de polarización por luz reflejada. Se obtienen, así, imágenes complementarias de una misma zona de la muestra.
In the first stage the polished clinker granule is submitted under vacuum $\left(10^{-1}\right.$ torr, at least) and, in this situation, the resin is introduced into the system.

In the second one, and in order to assure the complete filling, the partially impregnated sample (yet immersed in the resin) is subjected to a load of $100 \mathrm{kp} / \mathrm{cm}^{2}$ during $15 \mathrm{~min}$. In this way, the resin is forced to penetrate in all the pore interstices.

When the impregnation process has finished, the samples are allowed to dry, out of the vessel, only covered by a thin film of resin. When solidified, the film is removed by grinding with SiC F600. The sample preparation finishes with the normal stages of rough and fine polishing.

\section{CONCLUSIONS}

The fluorescence light microscopy is an appropriate technique for the textural study of Portland cement clinker, as it permits an optimum observation of porosity.

The sample preparation allows the consolidation of brittle clinkers because of its ability to fill all the voids of the samples.

The samples can also be observed by reflected light polarizing microscopy. So, complementary images can be obtained from the same area of the sample. 
Las imágenes obtenidas, dadas sus características, son muy apropiadas para su estudio y cuantificación mediante técnicas automatizadas, como el proceso digital de imágenes.
The obtained images, taking into account their characteristics, are very proper for their study and quantification by automated techniques, as digital image processing.

\section{DIBLIOGRAFIA}

[1] GOUDA, G. R.: "Effect of clinker composition on grindability". Cem. Concr. Res., Vol. 9, 1979, pp. $209-210$.

[2] PETERSEN, I. F.: "The pore structure and the grindability of clinker". Cim. Bet. Plat. Chaux, n. 726,1980, pp. 297-301.

[3] WALKER, H. N.: "Examination of Portland cement concrete by fluorescent light microscopy". Proc. Iil. Int. Confer. Cement Microscopy, pp. 257-278. G.R. Gouda, Ed. Houston, USA, 1981.

[4] RODRIGUEZ REY, A.: "Aplicación de la microscopia óptica y electrónica al estudio mineralógico y textural del ciínker de cemento Portland". Tesis Doctoral. Universidad de Oviedo, 1986.

[5] SCHAEFER, A.: "Fluorescence Microscopy" in Encyclopedia of Microscopy and Microtechnique, P. Gray, Ed. Van Nostrand Reinhold, Nueva York, 1981.

[6] PERAMI, R.: "Contribution a l'étude experimentale de la microfissuration des roches sous actions mécaniques et thérmiques". Tesis Doctoral. Universidad Paul Sabatier. Toulouse, 1971.

[7] GRANDA, J. R.: "Valoración cuantitativa de la fisuración interna de las rocas en función de esfuerzos compresivos uniaxiales". Tesis de Licenciatura. Universidad de Oviedo, 1978.

[8] SUAREZ DEL RIO, L. M.: "Estudio petrofísico de materiales graníticos geomecánicamente diferentes". Tesis Doctoral. Universidad de Oviedo, 1982.

\section{publicación del i.e.t.c.c.}

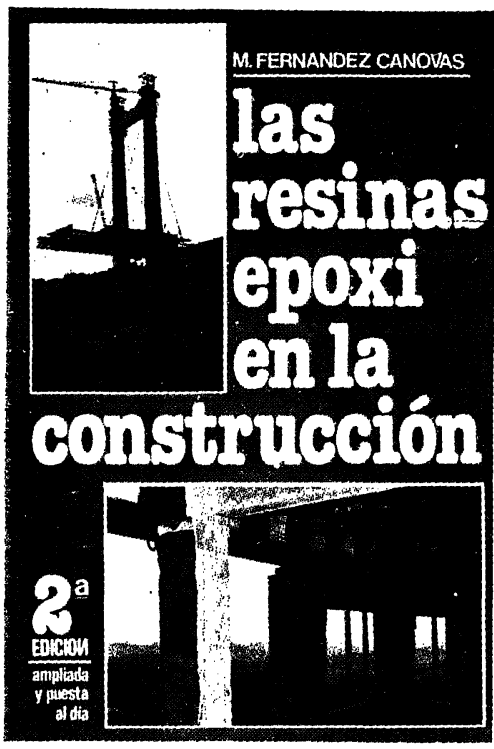

22

\section{Manuel Fernández Cánovas}

Dr. Ingeniero de Construcción

Este libro, el primero en lengua castellana sobre resinas epoxi aplicadas a la construcción, está dirigido a arquitectos, ingenieros, constructores y aplicadores. En él, sobre una reducida base teórica imprescindible, se asienta toda una extensa gama de aplicaciones de gran interès.

El autor trabaja desde hace muchos años en el campo de la investigación, especialmente en el estudio de refuerzos y reparaciones estructurales realizados con resinas epoxi.

Con un ienguaje sencillo se tocan todos los problemas que pueden presentarse en la construcción y en los que la solución puede radicar en el correcto empleo de las resinas epoxi.

Se estudian los componentes de las formulaciones epoxi, sus propiedades fisicas y quimicas, y aplicaciones, deteniéndose, detalladamente, en las siguientes:

Unión de hormigón fresco a hormigón endurecido. -... Unión de hormigones entre si.-Inyecciones de fisuras y grietas. - Unión de acero a hormigón. Barnices y pinturas. - Las combinaciones brea-epoxi. - Revestimientos de depositos alimenticios. … Sellado de superficies ceramicas. - Protección de tubos. -- Los suelos epoxi en sus diferen tes variantes. . Terrazo epoxi. -.. Reparación de baches. -Reparación de desperfectos en estructuras. - Reparación de carreteras de hormigón. ... Juntas elásticas.... Guardacantos de tableros de puentes. ... Refuerzos de pilares, vigas, forjados y <apatas, etc. Consolidación de suelos.- Anclajes. -- Protección de aceros en pretensado.

Se termina con unos capitulos dedicados a la limpieza y preparación de las superficies según los materiales a unir; al control del estado superficial de èstos; a las condiciones de temperatura de aplicación; limpieza de los útiles de métodos de ensayo de sistemas y aplicaciones epoxidicas.

Un volumen encuadernado en cartoné plastificado con lomo de tela, de $17 \times 24 \mathrm{~cm}$, compuesto de 334 páginas y 158 figuras y fotografias.

Madrid, 1981.

Precios: España, 1.700 ptas.; extranjero, \$ USA 34.00

MATERIALES DE COSTRUCCION, Vol. 37, n. 205, enero/febrero/marzo 1987 